\section{Mutational analysis of candidate genes in 24 amelogenesis imperfecta families}

\author{
Kim J-W, Simmer JP, Lin BP-L, Seymen F, Bartlett JD, Hu JC-C. Mutational analysis \\ of candidate genes in 24 amelogenesis imperfecta families. Eur J Oral Sci 2006; 114 \\ (Suppl. 1): 3-12 (c) Eur J Oral Sci, 2006 \\ Amelogenesis imperfecta (AI) is a heterogeneous group of inherited defects in dental \\ enamel formation. The malformed enamel can be unusually thin, soft, rough and \\ stained. The strict definition of AI includes only those cases where enamel defects \\ occur in the absence of other symptoms. Currently, there are seven candidate genes for \\ AI: amelogenin, enamelin, ameloblastin, tuftelin, distal-less homeobox 3, enamelysin, \\ and kallikrein 4. To identify sequence variations in AI candidate genes in patients with \\ isolated enamel defects, and to deduce the likely effect of each sequence variation on \\ protein expression and structure, families with isolated enamel defects were recruited. \\ The coding exons and nearby intron sequences were amplified for each of the AI \\ candidate genes by using genomic DNA from the proband as template. The amplifi- \\ cation products for the proband were sequenced. Then, other family members were \\ tested to determine their genotype with respect to each sequence variation. All subjects \\ received an oral examination, and intraoral photographs and dental radiographs were \\ obtained. Out of 24 families with isolated enamel defects, only six disease-causing \\ mutations were identified in the AI candidate genes. This finding suggests that many \\ additional genes potentially contribute to the etiology of AI.
}

Jung-Wook Kim ${ }^{1,2}$, James $\mathrm{P}$. Simmer ${ }^{1}$, Brent P.-L. Lin ${ }^{3}$, Figen Seymen $^{4}$, John D. Bartlett ${ }^{5}$, Jan C.-C. $\mathrm{Hu}^{1}$

${ }^{1}$ University of Michigan School of Dentistry, University of Michigan Dental Research Laboratory, Ann Arbor, MI, USA; ${ }^{2}$ Seoul National University, College of Dentistry, Department of Pediatric Dentistry \& Dental Research Institute, Seoul, Korea; ${ }^{3}$ UCSF School of Dentistry, Department of Growth and Development, San Francisco, CA, USA; ${ }^{4}$ University of Istanbul, Faculty of Dentistry, Department of Pedodontics, Çapa, Istanbul, Turkey; ${ }^{5}$ The Forsyth Institute, Harvard-Forsyth Department of Oral Biology, Boston, MA, USA

Jan C.-C. Hu, BDS, PhD, Department of Orthodontics and Pediatric Dentistry, University of Michigan Dental Research Laboratory, 1210 Eisenhower Place, Ann Arbor, MI 48108, USA

Telefax: +1-734-9759329

E-mail: janhu@umich.edu

Key words: amelogenesis imperfecta; AMELX; ENAM; enamel; MMP20

Accepted for publication October 2005
Inherited enamel defects that occur in the absence of a generalized syndrome are collectively designated as amelogenesis imperfecta (AI). For reviews of the clinical features and classification of AI, refer to the classic works of Witkop $(1,2)$. Currently, there are five proven candidate genes for AI: amelogenin $(A M E L X)$, enamelin $(E N A M)$, enamelysin $(M M P 20)$, kallikrein 4 (KLK4), and distal-less homeobox $3(D L X 3)$. There are also two unproven candidate genes: ameloblastin $(A M B N)$ and tuftelin (TUFT1). In the subsequent text, we review the mutations that have been shown, to cause different forms of AI. Then, we present our mutational analyses of the AI candidate genes in 24 families with inherited enamel defects, and discuss what the low success rate in finding new mutations means in terms of our understanding of the molecular participants in normal enamel formation and the state of our understanding of the genetic etiologies of AI.

\section{X-linked Al}

$\mathrm{X}$-linked AI accounts for $\approx 5 \%$ of all AI cases ( 3 ), and is caused by defects in the amelogenin gene on the $\mathrm{X}$-chromosome (Xp22.3-p22.1). While there is a second amelogenin gene on the $\mathrm{Y}$-chromosome (AMELY), this gene is expressed at low levels (4), does not appear to be necessary for proper dental enamel formation, and does not contribute to the etiology of AI. X-linked AI has a distinctive pattern of inheritance: there are likely to be twice as many affected females as males, and affected males transmit the AI trait to all of their daughters but to none of their sons. Potentially more diagnostic than the pattern of inheritance (which may not be obvious in small families with few affected members) is the distinctive vertical banding pattern on the enamel of affected females. These vertical bands are believed to be caused by the presence of alternating bands of ameloblasts secreting normal and defective amelogenin during amelogenesis $(1,5)$.

The $\mathrm{X}$ and $\mathrm{Y}$ chromosomal copies of the human amelogenin genes do not undergo homologous recombination, so, over time, their sequences have diverged (6). The differences make $A M E L X$ and $A M E L Y$ useful for sex determination in forensics. For this purpose, oligonucleotide primer pairs are used that give different-size polymerase chain reaction (PCR) amplification products for $A M E L X$ and $A M E L Y$ (7). There is a small failure rate for the amelogenin sex test, caused by the rare deletion of AMELY (8), which can reach as high as $3.6 \%$ in particular ethnic groups in Malaysia and India (9). Two individuals with $A M E L Y$ deletions reportedly had normal teeth (10).

As of the time of writing this report, 14 different disease-causing mutations have been identified in $A M E L X$, which are described by a standardized nomenclature (11). The designations, based upon their predicted effect on translation of the amelogenin protein, are: p.0 (12); p.W4S and p.M1T (13); p.W4X (14); p.H129fs187 (15); 
p.I5-A8delinsT (16); p.T51I, p.P158fs187, and p.E191X (17); p.P52fsX53 (18,19); p.P70T (20-22); p.H77L (23); p.Y141fs187 (24); and p.L181fs187 (23,25). Different phenotypic patterns appear to correlate with mutations affecting three different regions of the amelogenin protein (26).

\section{Autosomal-dominant Al}

An autosomal-dominant pattern of inheritance is easily recognized by analysis of the pedigree. Men and women are affected equally, and an affected person and an unaffected person are likely to have an equal number of affected and unaffected children. The candidate genes for autosomal-dominant forms of AI (ADAI) are the genes encoding enamel matrix proteins: enamelin and ameloblastin (4q11-q21) (27,28), and tuftelin (1q21-31) (29). Autosomal-dominant AI was first linked to chromosome $4 \mathrm{q}(30)$, in a region since shown to contain the ameloblastin $(31,32)$ and enamelin genes (28). Subsequent studies, however, only detected mutations in the enamelin gene (33-39). Other genes besides enamelin are certain to participate in the etiology of ADAI; as linkage outside the $4 \mathrm{q}$ region (40), as well as outside the loci for all of the known AI candidate genes (41), has been established.

The enamelin gene $(E N A M, 4 \mathrm{q} 13)$ has 10 exons, eight of which are coding $(42,43)$. As of the time of writing this report, five different disease-causing mutations have been identified in ENAM, which are described by a standardized nomenclature (35). The designations of the mutations are based upon their predicted effect on translation of the enamelin protein: p.K53X (39); p.M71Q157del (33) and p.A158-Q178del (36); p.N197fsX277 $(33,35,38)$; and p.P422fsX448 (34). Mutations in ENAM produce a hypoplastic (thin enamel) phenotype. In its mildest form, very minor pits are evident (34). Sometimes there are horizontal lines of hypoplastic enamel, especially in the cervical third of the crown.

No disease-causing mutations have yet been found in the ameloblastin gene $(A M B N, 4 \mathrm{q} 13)$. Ameloblastin (27), which has also been referred to as amelin (44) and sheathlin (45), is a proven constituent of the enamel matrix of developing teeth (46). $A M B N$-null mice develop severe enamel hypoplasia in the homozygousnegative $\left(\mathrm{Ambn}^{--}\right)$condition (47). There is little doubt that $A M B N$ mutations will one day be shown to cause AI. We suspect that $A M B N$ is normally secreted in sufficient quantities so that a reduction in $A M B N$ expression, as a result of haploinsufficiency, may not produce an obvious dental phenotype. If so, $A M B N$ mutations would be part of the etiology of autosomal-recessive forms of AI.

\section{Autosomal-dominant hypoplastic-hypomaturation Al with taurodontism}

The autosomal-dominant hypoplastic-hypomaturation AI with taurodontism (AIHHT) form of AI is a variation of tricho-dento-osseous syndrome (TDO), which is an autosomal-dominant disorder named for the most com- monly affected tissues: hair, teeth, and bones $(48,49)$. The genetic cause of TDO was linked to the $D L X 3$ gene on chromosome 17q21 (50), and mutational analyses identified a 4-bp deletion in $D L X 3$ that caused the disease $(51,52)$. While the principal clinical features of TDO include kinky or curly hair in infancy, enamel hypoplasia, taurodontism, and increased thickness and density of cranial bones, the most penetrant feature in some kindreds may be the dental phenotype, as a 2-bp deletion in the $D L X 3$ gene has now been reported to cause AIHHT (53).

\section{Autosomal-recessive Al}

When a condition is inherited in an autosomal-recessive pattern, the affected person must have two abnormal alleles of the disease gene to manifest a phenotype. Heterozygotes are phenotypically normal (even though they usually express a reduced amount of the given protein), but are carriers of the trait. Both parents are usually normal phenotypically and one in four of the children are likely to be affected. When one parent shows the phenotype and the other parent is a carrier, half of their children are likely to be affected. Consanguinity (inbreeding) may be a factor as related persons are more likely to share the same mutant allele. The diversity of clinical enamel phenotypes observed in autosomalrecessive AI (ARAI) is remarkable and may be indicative of a large number of potential candidate genes (54).

Two proteinases - enamelysin (55) and kallikrein-4 (previously designated enamel matrix serine proteinase 1, or EMSP1) - are normally secreted into the enamel extracellular space during amelogenesis (56). Enamelysin (MMP-20) is a matrix metalloproteinase that is primarily expressed during the secretory or early stage of amelogenesis (57-59), while KLK4 is a serine protease that is primarily secreted during the transition/maturation or later stages $(57,60)$. Mutations in the genes encoding these 'enamel proteases' form part of the etiology of ARAI.

In humans, enamelysin is expressed from the MMP20 gene on chromosome 11q22.3-q23, which has 10 exons. All are coding (61-63). The dental phenotype caused by a splice junction mutation (IVS6-2A $>\mathrm{T}$ ), affecting both MMP2O alleles, corresponded to an autosomal-recessive pigmented hypomaturation type of AI (2). The teeth were normal in size, but pigmented, showing an agar-brown discoloration. The enamel surface was mottled and rough. Chunks of enamel had fractured away from several teeth, and the enamel layer was radiographically more opaque than the underlying dentin, but not in all areas, and was never as radiopaque as normal enamel. The proband had an anterior open bite.

The human kallikrein $4(K L K 4)$ gene on chromosome $19 q 13.3-$ q13.4 has six exons, five of which are coding $(64,65)$. The AI subtype resulting from the nonsense mutation (p.W153X) in both KLK4 alleles was the autosomal-recessive pigmented hypomaturation type of AI (66). The teeth were normal in size and morphology, but had a generally yellow-brown color, were sensitive to hot and cold stimuli, and were painful during chewing. On dental radiographs the enamel was of normal thick- 
Table 1

Primers for TUFT1, AMBN, and DLX3 gene characterizations

\begin{tabular}{|c|c|c|c|c|}
\hline Name & Oligonucleotide sequence & Anneal & $\begin{array}{l}\text { Extension } \\
\text { temperature }\end{array}$ & $\begin{array}{l}\text { Extension } \\
\text { time }\end{array}$ \\
\hline \multicolumn{5}{|c|}{ Primers used to amplify and sequence the TUFT1 gene } \\
\hline TUFT1x1F & 5'-GCCCCACCTTTGTGTAAATC & $60^{\circ} \mathrm{C}$ & $72^{\circ} \mathrm{C}$ & $30 \mathrm{~s}$ \\
\hline TUFT1x1R & 5'-CCAGGTGATGTCAGCCAAC & $60^{\circ} \mathrm{C}$ & $72^{\circ} \mathrm{C}$ & $30 \mathrm{~s}$ \\
\hline TUFT1x23F & 5'-GATAAGACCCGCTCCACAGA & $60^{\circ} \mathrm{C}$ & $72^{\circ} \mathrm{C}$ & $60 \mathrm{~s}$ \\
\hline TUFT1x23R & 5'-GGTCTGGTTCCTTCCATCAA & $60^{\circ} \mathrm{C}$ & $72^{\circ} \mathrm{C}$ & $60 \mathrm{~s}$ \\
\hline TUFT1x23R1 & 5'-TAGTGGGGGACTCCТCCTG & Sequencing only & $72^{\circ} \mathrm{C}$ & $30 \mathrm{~s}$ \\
\hline TUFT1x45F & 5'-GATCCGAATCACCAAATTCC & $60^{\circ} \mathrm{C}$ & $72^{\circ} \mathrm{C}$ & $30 \mathrm{~s}$ \\
\hline TUFT1x45R & 5'-AGAGAAGCCAGCATCACCTC & $60^{\circ} \mathrm{C}$ & $72^{\circ} \mathrm{C}$ & $30 \mathrm{~s}$ \\
\hline TUFT1x45F1 & 5'-ACAGTGCCTGACTCGCAGTA & Sequencing only & $72^{\circ} \mathrm{C}$ & $30 \mathrm{~s}$ \\
\hline TUFT1x45R1 & 5'-ATGGTGGCATTTCAGAGACA & Sequencing only & $72^{\circ} \mathrm{C}$ & $30 \mathrm{~s}$ \\
\hline TUFT1x6F & 5'-TGTCСТTCTCTTTCTAAGATTTGAGT & $60^{\circ} \mathrm{C}$ & $72^{\circ} \mathrm{C}$ & $30 \mathrm{~s}$ \\
\hline TUFT1x6R & 5'-GAAAGCAATAAACAAAAGGATGG & $60^{\circ} \mathrm{C}$ & $72^{\circ} \mathrm{C}$ & $30 \mathrm{~s}$ \\
\hline TUFT1x7F & 5'-TTCCTGGCTGCCTAAGGTAA & $60^{\circ} \mathrm{C}$ & $72^{\circ} \mathrm{C}$ & $30 \mathrm{~s}$ \\
\hline TUFT1x7R & 5'-CTTGCCTTTCCAGTTTGTGG & $60^{\circ} \mathrm{C}$ & $72^{\circ} \mathrm{C}$ & $30 \mathrm{~s}$ \\
\hline TUFT1x89F & 5'-CCCATCAGTGTCACCACCTT & $60^{\circ} \mathrm{C}$ & $72^{\circ} \mathrm{C}$ & $60 \mathrm{~s}$ \\
\hline TUFT1x89R & 5'-GACATCAGCACCAGCTTCCT & $60^{\circ} \mathrm{C}$ & $72^{\circ} \mathrm{C}$ & $60 \mathrm{~s}$ \\
\hline TUFT1x89F1 & 5'-CССАТCAAACCAGCTCATCT & Sequencing only & $72^{\circ} \mathrm{C}$ & $60 \mathrm{~s}$ \\
\hline TUFT1x89R1 & 5'-GGGGAGGCTAATTCCTTGAA & Sequencing only & $72^{\circ} \mathrm{C}$ & $60 \mathrm{~s}$ \\
\hline TUFT1x10F & 5'-GAATCAGGCAAAGGGAATCA & $60^{\circ} \mathrm{C}$ & $72^{\circ} \mathrm{C}$ & $60 \mathrm{~s}$ \\
\hline TUFT1x10R & 5'-GAGCAACAGCAAGACATGACA & $60^{\circ} \mathrm{C}$ & $72^{\circ} \mathrm{C}$ & $60 \mathrm{~s}$ \\
\hline TUFT1x10F1 & 5'-CACCCCTGGGATAATCAAGA & Sequencing only & $72^{\circ} \mathrm{C}$ & $60 \mathrm{~s}$ \\
\hline TUFT1x10R1 & 5'-CAGTAGGGGAAAGATGGGAGA & Sequencing only & $72^{\circ} \mathrm{C}$ & $60 \mathrm{~s}$ \\
\hline TUFT1x12F & 5'-GGTAGAGGCAACAGCAGCA & $60^{\circ} \mathrm{C}$ & $72^{\circ} \mathrm{C}$ & $60 \mathrm{~s}$ \\
\hline TUFT1x12R & 5'-GTGCAGCCAGGGGACAGT & $60^{\circ} \mathrm{C}$ & $72^{\circ} \mathrm{C}$ & $60 \mathrm{~s}$ \\
\hline TUFT1x12F1 & 5'-ССССАAАТСТТССССТАGTT & Sequencing only & & \\
\hline TUFT1x12R1 & 5'-GGCAAACAGTGGGTCAGACT & Sequencing only & & \\
\hline \multicolumn{5}{|c|}{ Primers used to amplify and sequence the $A M B N$ gene } \\
\hline AMBNx1F & 5'-TGCCTTCCСТGCTATCAAGT & $53^{\circ} \mathrm{C}$ & $68^{\circ} \mathrm{C}$ & $30 \mathrm{~s}$ \\
\hline AMBNx1R & 5'-TGAATGGGTGTTAGGCATGT & $53^{\circ} \mathrm{C}$ & $68^{\circ} \mathrm{C}$ & $30 \mathrm{~s}$ \\
\hline $\mathrm{AMBNx} 2 \mathrm{~F}$ & 5'-CGATGGAGGTTGTTCCTACA & $53^{\circ} \mathrm{C}$ & $68^{\circ} \mathrm{C}$ & $30 \mathrm{~s}$ \\
\hline$A M B N x 2 R$ & 5'-TCACCTCAGGTCATCCTCCT & $53^{\circ} \mathrm{C}$ & $68^{\circ} \mathrm{C}$ & $30 \mathrm{~s}$ \\
\hline $\mathrm{AMBNx} 3 \mathrm{~F}$ & 5'-ATGCAGGTGGGAGCAAAAT & $53^{\circ} \mathrm{C}$ & $68^{\circ} \mathrm{C}$ & $30 \mathrm{~s}$ \\
\hline AMBNx3R & 5'-TTGCTTTGGTTTGCATAGAA & $53^{\circ} \mathrm{C}$ & $68^{\circ} \mathrm{C}$ & $30 \mathrm{~s}$ \\
\hline $\mathrm{AMBNx} 4 \mathrm{~F}$ & 5'-TGGGGAGAAAGAGTCAATGAA & $53^{\circ} \mathrm{C}$ & $68^{\circ} \mathrm{C}$ & $40 \mathrm{~s}$ \\
\hline AMBNx4R & 5'-TTTCGTTTTGAGCTAGTCTGC & $53^{\circ} \mathrm{C}$ & $68^{\circ} \mathrm{C}$ & $40 \mathrm{~s}$ \\
\hline AMBNx5F & 5'-GTGGTGCGTGCCTGTAGAC & $56^{\circ} \mathrm{C}$ & $68^{\circ} \mathrm{C}$ & $30 \mathrm{~s}$ \\
\hline AMBNx5R & 5'-TCCAGGATGTAGCCTGCTTT & $56^{\circ} \mathrm{C}$ & $68^{\circ} \mathrm{C}$ & $30 \mathrm{~s}$ \\
\hline AMBNx5F1 & 5'-CAAATATAACCAATGTTATATTTAAC & Sequencing only & $68^{\circ} \mathrm{C}$ & $30 \mathrm{~s}$ \\
\hline AMBNx5R1 & 5'-CTTCGATTTATTTGGCACGA & Sequencing only & $68^{\circ} \mathrm{C}$ & $30 \mathrm{~s}$ \\
\hline AMBNx6F & 5'-TCСТAGCСТСССТTCCAGAT & $53^{\circ} \mathrm{C}$ & $68^{\circ} \mathrm{C}$ & $30 \mathrm{~s}$ \\
\hline AMBNx6R & 5'-ATCCATGCCCTGTCTCTGAT & $53^{\circ} \mathrm{C}$ & $68^{\circ} \mathrm{C}$ & $30 \mathrm{~s}$ \\
\hline AMBNx7-9F & 5'-TTGGGTCATACCTCCСAAAA & $60^{\circ} \mathrm{C}$ & $68^{\circ} \mathrm{C}$ & $40 \mathrm{~s}$ \\
\hline AMBNx7-9R & 5'-ACAGGCACATCCCCATAACA & $60^{\circ} \mathrm{C}$ & $68^{\circ} \mathrm{C}$ & $40 \mathrm{~s}$ \\
\hline AMBNx10-11F1 & 5'-TTTCATTGTCCСАTTTATCCA & $52^{\circ} \mathrm{C}$ & $68^{\circ} \mathrm{C}$ & $30 \mathrm{~s}$ \\
\hline AMBNx10-11R1 & 5'-GAGGCAAAGTGGAGAGGTGA & $52^{\circ} \mathrm{C}$ & $68^{\circ} \mathrm{C}$ & $30 \mathrm{~s}$ \\
\hline AMBNx12F & 5'-GGAGGCAAACTTCCTATTTGG & $56^{\circ} \mathrm{C}$ & $68^{\circ} \mathrm{C}$ & $30 \mathrm{~s}$ \\
\hline AMBNx12R & 5'-GCCTTTCAAGGGGAGTTTTC & $56^{\circ} \mathrm{C}$ & $68^{\circ} \mathrm{C}$ & $30 \mathrm{~s}$ \\
\hline AMBNx12R1 & 5'-GAGGCAAAGTGGAGAGGTGA & Sequencing only & $68^{\circ} \mathrm{C}$ & $60 \mathrm{~s}$ \\
\hline AMBNx13F & 5'-CСССАAАТСТТССССТАGTT & $55^{\circ} \mathrm{C}$ & $68^{\circ} \mathrm{C}$ & $60 \mathrm{~s}$ \\
\hline AMBNx13R & 5'-GGCAAACAGTGGGTCAGACT & $55^{\circ} \mathrm{C}$ & $68^{\circ} \mathrm{C}$ & $60 \mathrm{~s}$ \\
\hline AMBNx13F1 & 5'-GAAGAAGGAGGTGCACAAGG & Sequencing only & & \\
\hline AMBNx13R1 & 5'-GGGGAGCAGGTTCTAGCTCT & Sequencing only & & \\
\hline \multicolumn{5}{|c|}{ Primers used to amplify and sequence the $D L X 3$ gene } \\
\hline DLX3X1F & 5'-CAAGACTTGCAGCCAATCAG & $58^{\circ} \mathrm{C}$ & $72^{\circ} \mathrm{C}$ & $30 \mathrm{~s}$ \\
\hline DLX3x1R & 5'-GGGAACCTTCCAGTGTCTCC & $58^{\circ} \mathrm{C}$ & $72^{\circ} \mathrm{C}$ & $30 \mathrm{~s}$ \\
\hline DLX3x2F & 5'-AAGGCGTCGTGAGCGAAG & $58^{\circ} \mathrm{C}$ & $72^{\circ} \mathrm{C}$ & $30 \mathrm{~s}$ \\
\hline DLX3x2R & 5'-AAAGGCAAGAGTTCCAGGAG & $58^{\circ} \mathrm{C}$ & $72^{\circ} \mathrm{C}$ & $30 \mathrm{~s}$ \\
\hline DLX3x2F1 & 5'-CTGGAGGGTCGCAGGAGT & Sequencing only & $72^{\circ} \mathrm{C}$ & $30 \mathrm{~s}$ \\
\hline DLX3x3F & 5'-ATTGGGTTCTGGCCTTTCTT & $58^{\circ} \mathrm{C}$ & $72^{\circ} \mathrm{C}$ & $30 \mathrm{~s}$ \\
\hline DLX3x3R & 5'-GCCTTCTGCCTGGTCCTG & $58^{\circ} \mathrm{C}$ & $72^{\circ} \mathrm{C}$ & $30 \mathrm{~s}$ \\
\hline
\end{tabular}




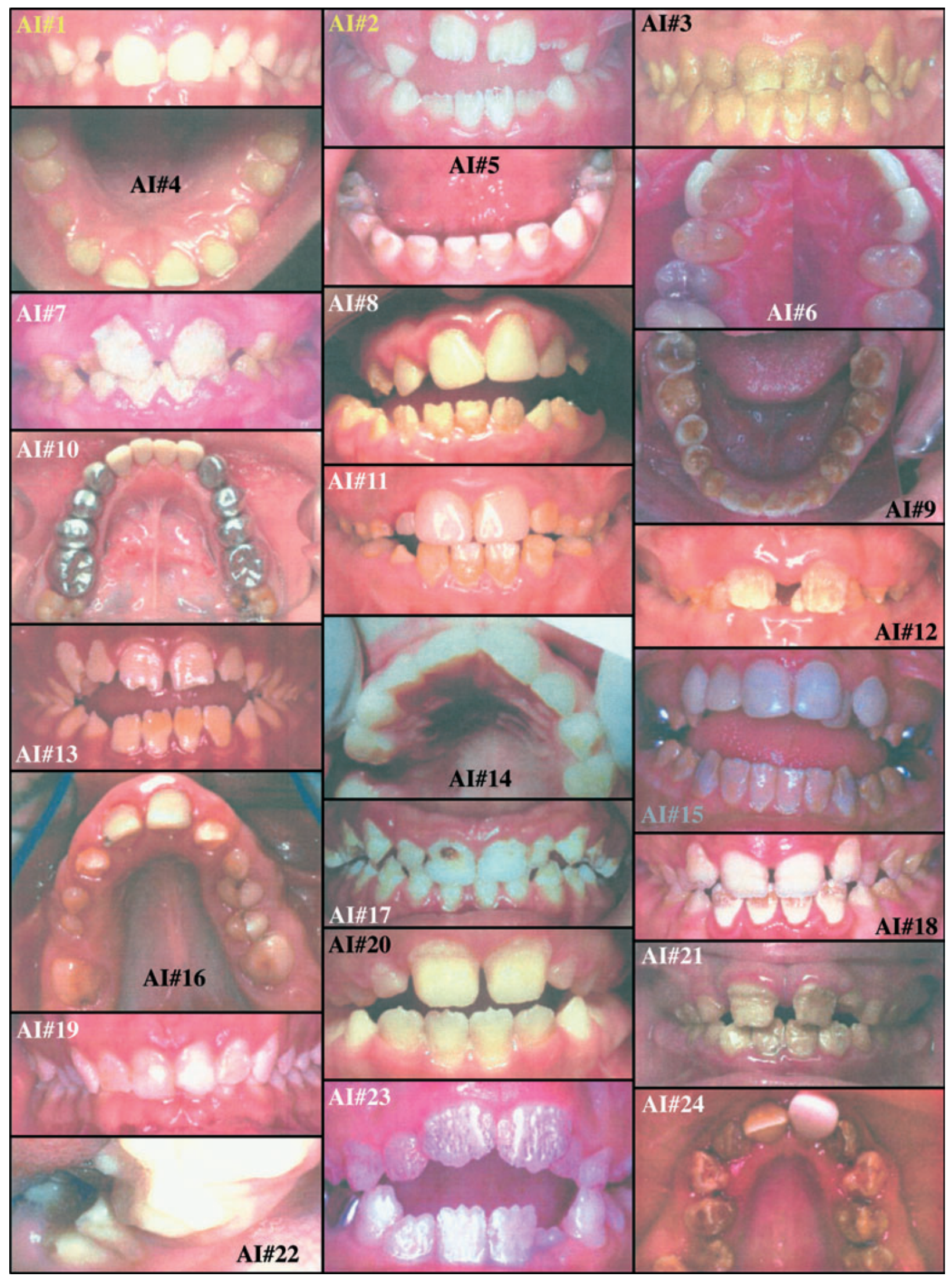


ness, but had only slightly greater opacity than the underlying dentin. The enamel tended to fracture from the occlusal surfaces of the primary molars.

\section{Material and methods}

The human study protocol and patient consents were reviewed and approved by the Institution Review Boards at the University of Michigan.

Twenty-four families with isolated enamel defects were recruited for mutational analyses. The coding exons and nearby intron sequences were amplified for each of the seven candidate genes for AI: amelogenin (AMELX, Xp22.3p22.1), enamelin (ENAM, 4q11-q21), ameloblastin ( $A M B N, 4 \mathrm{q} 11-\mathrm{q} 21)$, tuftelin (TUFT1, 1q21-31), enamelysin (MMP20, 11q22), Kallikrein-4 (KLK4, 19q13.3-q13.4) and distal-less 3 ( $D L X 3,17 \mathrm{q} 21)$, using genomic DNA from the proband as template. The amplification products were characterized by DNA sequencing and then other family members were tested to determine their genotype with respect to each sequence variation, but, typically, the number of people in each family was too few for haplotype analyses. All subjects received an oral examination, and intraoral photographs and dental radiographs were obtained.

In most cases, $15 \mathrm{ml}$ of peripheral whole blood was obtained from participating family members. Alternatively, buccal swabs were performed. High-molecular-weight genomic DNA was isolated using the QIAamp DNA Blood Maxi Kit and protocol (Qiagen, Valencia, CA, USA). Ten nanograms of genomic DNA from affected individuals was amplified using Platinum PCR Supermix or Platinum Tag High Fidelity (Invitrogen, Carlsbad, CA, USA). Polymerase chain reaction amplification products were purified by using the QIAquick PCR Purification Kit and protocol (Invitrogen). The concentration of purified amplimer was estimated by the intensity of its ethidium bromide-stained band on a $1 \%$ agarose gel, adjusted to $1 \mathrm{ng} \mu \mathrm{l}^{-1}$ for each $100 \mathrm{bp}$ of fragment size, and then a $3.2 \mathrm{pmol} \mu \mathrm{l}^{-1}$ aliquot of oligonucleotide primer was used in the sequencing reactions. DNA sequencing was performed on an ABI Model 3700 DNA sequencer (Applied Biosystems, Foster City, CA, USA) at the University of Michigan DNA sequencing core (http://seqcore.brcf.med.umich.edu/doc/dnaseq/ intro.html).

The primer pairs and PCR conditions for amplification of the coding regions of $A M E L X$ (13), ENAM (33), KLK4 (66), and MMP20 (67) were as described previously. The primers and PCR conditions for amplification of the coding exons for $A M B N, T U F T 1$, and $D L X 3$ are provided in Table 1.

\section{Results}

We recruited 24 families with inherited enamel defects. Oral photographs of the proband's dentition, and pedigree drawings of the families, are shown in Figs 1 and 2 , respectively. The dental phenotypes of the 24 probands were highly variable and often did not correspond strictly to the 14 classical AI subtypes (2). In two cases the diagnosis of amelogenesis imperfecta was questionable: a reviewer of this manuscript commented that the oral photograph of the family 6 proband was more suggestive of dentinogenesis imperfecta, and the enamel phenotype of the family 3 proband was similar to that observed in vitamin D-dependent rickets type I (68).

In this study, a sequence variation was considered to be disease-producing when the mutation correlated with the enamel phenotype in the available family members and the effects of the mutation on the enamel protein structure or its expression level was predicted to be significant. Two of the families showed an X-linked pattern of inheritance, and disease-causing $A M E L X$ mutations (\#1/p.M1T and \#2/p.W4S) were identified in these kindreds (13). Eleven families showed a dominant pattern of inheritance (\#6, 7, 8, 10,11, 13, 17, 19, 21, 23, and 24). Disease-causing ENAM mutations were identified in three of these kindreds (\#13, 17, and 19). Two of these mutations (\#13/g.8344delG and \#17/g.4806A $>C$ ) we reported previously (33). The third ENAM mutation (\#19/p.K53X) is identical to that identified in Sweden (39). Our p.K53X proband showed linear horizontal enamel defects concentrated at the cervical third of permanent incisors. Radiographically, his enamel had a radiodensity that could be distinguished from the underlying dentin; however, enamel formation fell short of the cervical regions in many teeth. Enamel was missing from the cervical third of many anterior teeth (Fig. 1, \#19). On the permanent premolars and molars, enamel covered only the coronal and middle thirds of the crowns, although the patient did not report any increased thermal sensitivity. The enamel phenotype in the proband is very similar to that observed in the Swedish family with the p.K53X defect in ENAM.

No disease-causing mutations were identified in the other families with dominant forms of amelogenesis imperfecta. One family (\#15) had a pseudodominant pattern of inheritance. This was shown to be a recessive case, with both MMP20 alleles in the proband and his father having the same disease-causing mutation (g. 30,561A > T) (67). Ten of the kindreds $(\# 3,4,5,9,12$, $14,16,18,20$, and 22) only displayed an enamel phenotype in a single generation, and the pattern of inheritance could not be assigned with certainty. Six of these families had only one affected member. A number of sequence variations were identified in these families, but none met our criteria for being specified as diseasecausing.

In the text below we describe candidate gene sequence variations that we identified in the 24 AI probands, but concluded, after analysis, that were unlikely to cause the disease.

Fig. 1. Clinical photographs of probands in each family. The amelogenesis imperfecta (AI) in families \#1 and \#2 was caused by p.M1T and p.W4S mutations in AMELX, respectively (13). The AI in families \#13 and \#17 was caused by p.N197fsX277 and IVS6$2 \mathrm{~A}>\mathrm{C}$ mutations in ENAM, respectively (33). The AI in family \#15 was caused by an IVS6-2A $>$ T mutation in both $M M P 20$ alleles (67). Pattern of inheritance color key for kindred numbers: X-linked, yellow; autosomal dominant, white; pseudodominant, gray; not discerned, black. 

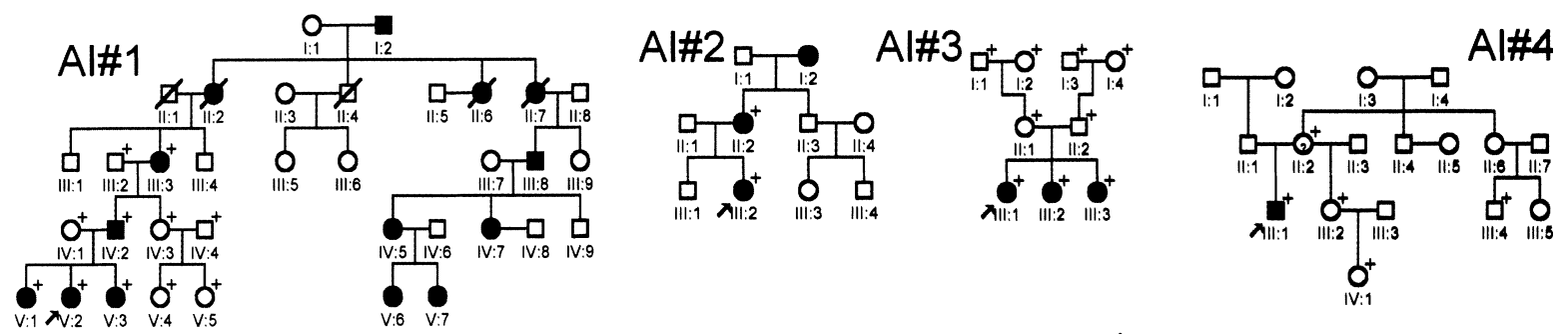

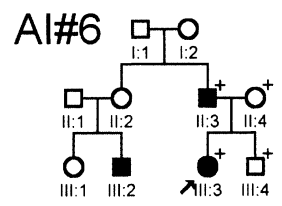

Al\#7

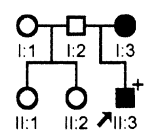

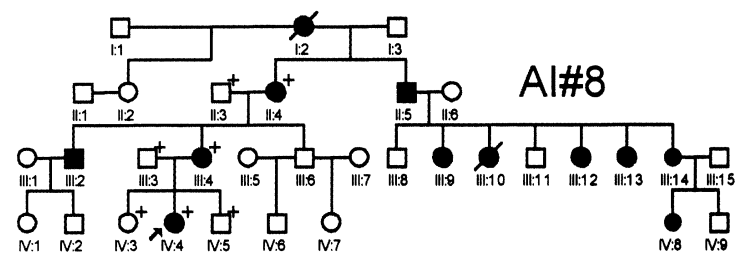

Al\#9
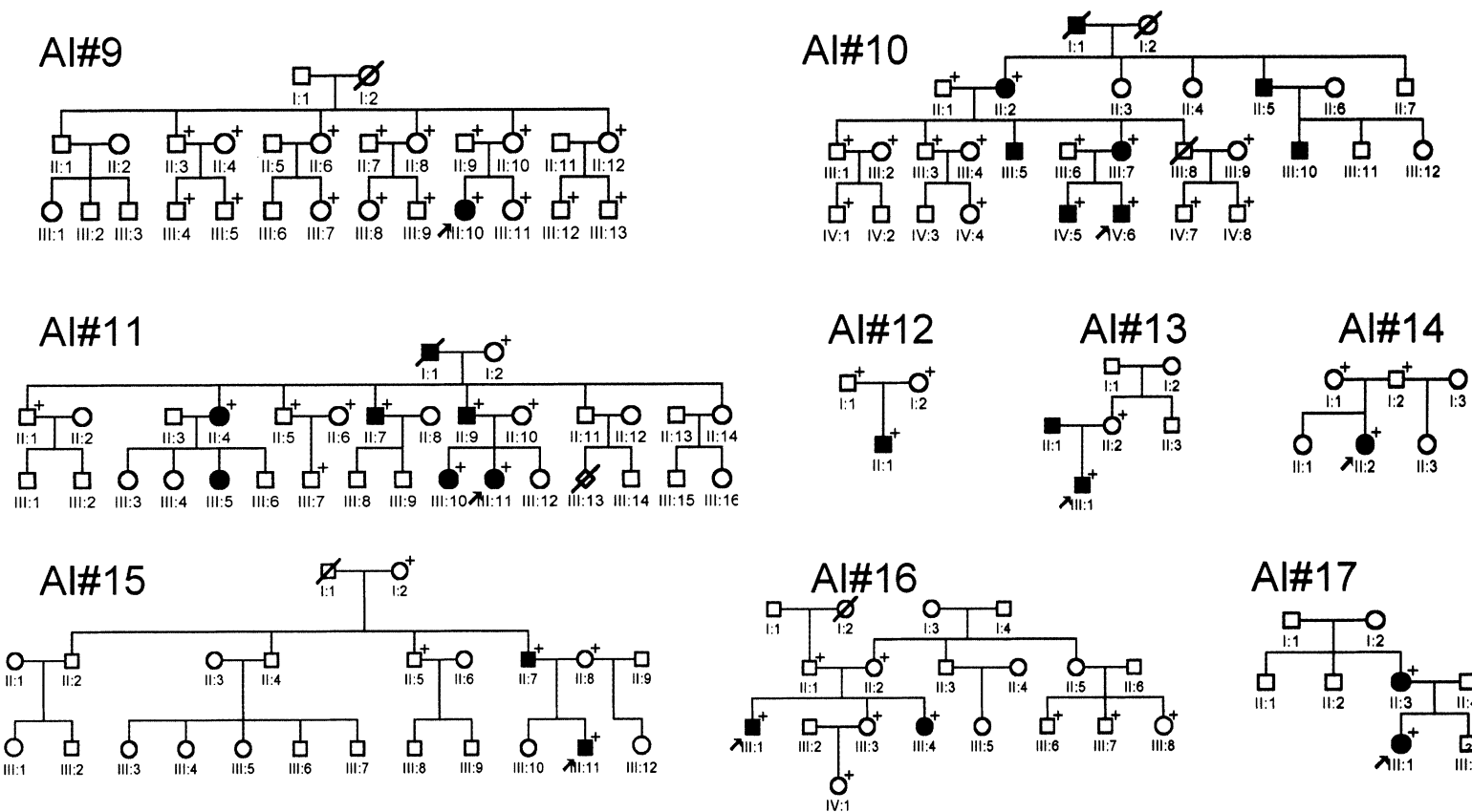

Al\#17
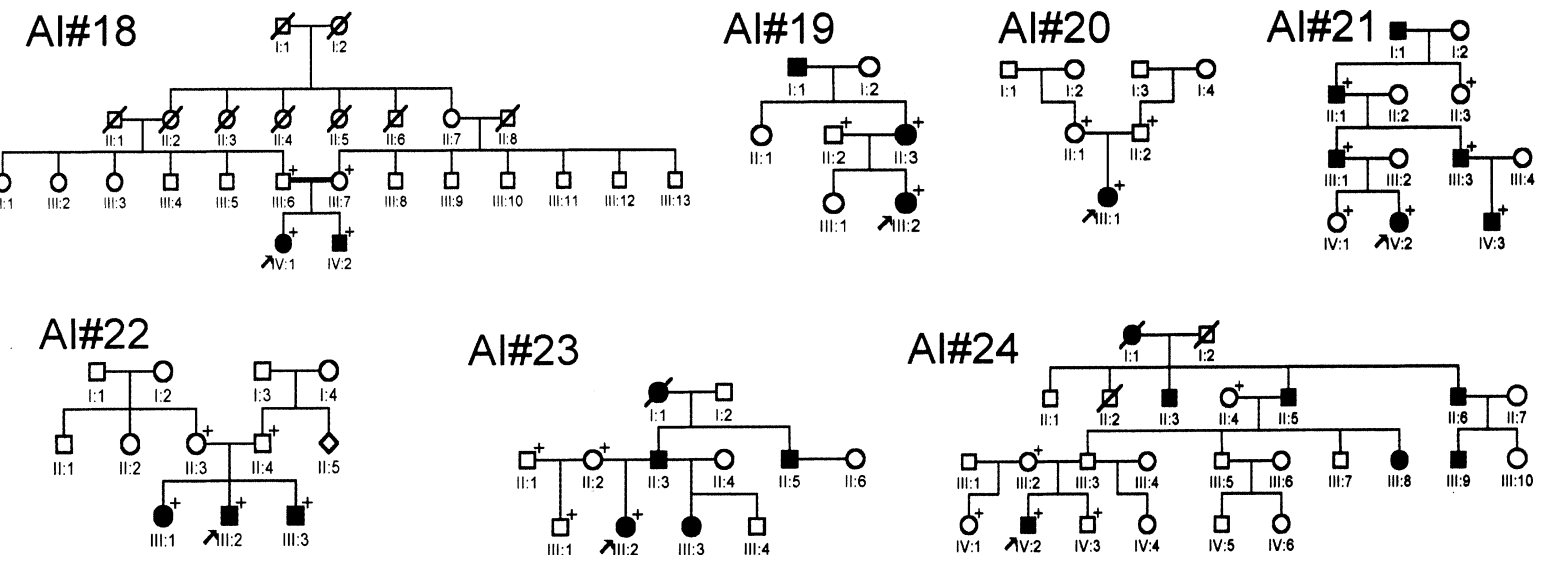

Fig. 2. Pedigree drawings of each family. The proband, or the affected member who brought the family to the attention of the study, is indicated by an arrow. Key: square, male; circle, female; a filled symbol indicates AI phenotype; a diagonal line indicates deceased; $\mathrm{a}+$ identifies members recruited in the study. 


\section{AMELX}

A g.- $11 \mathrm{~A}>\mathrm{G}$ change in $A M E L X$ was identified in the proband of family \#21, but an X-linked pattern of inheritance was ruled out by analysis of the pedigree.

\section{TUFT1, DLX3 and ENAM}

Several sequence variations were identified in TUFT1, $D L X 3$, and $E N A M$, but all were found in the SNP database (http://www.ncbi.nlm.nih.gov/SNP). As the mutations were not predicted to cause significant changes in protein structure or expression, and they are represented in the general population, they are unlikely to be disease-causing.

\section{KLK4}

In family \#4, a $\mathrm{G}$ to A change (c.476G > A, p.G159D) was identified in $K L K 4$ at the first nucleotide of exon 5. The phenotype of the proband (III-1) was smooth hypoplastic type and the mother (II-2) had pits in the cusp tips of her maxillary canines and first bicuspids. Another family member (III-2) had the same nucleotide change but a normal dental phenotype. The previously reported KLK4 disease phenotype (66), and the difference in phenotype between the proband and the other members, argues against this sequence variation causing the disease (i.e. showing a lack of penetrance and variable expressivity).

\section{MMP20}

In family \#24, a $\mathrm{G}$ to $\mathrm{C}$ change (c.1313G $>\mathrm{C}$, p.G438A) in $M M P 20$ was identified in the proband, but the unaffected mother (III-2) also had the same sequence variation.

\section{AMBN}

Before the new version of the human genome (http:// www.ncbi.nlm.nih.gov/genome, Homo sapiens Build 35.1 ), there were two deletions in the $A M B N$ genomic sequence relative to its cDNA sequence (NM_016519): c.538-540delGGA (p.G180del) and c.634-636delCCA (p.P212del). Now the new version of the genome has the same sequence as the $A M B N$ mRNA. In family $\# 8$, c.538-540delGGA (p.G180del) was identified in one allele, but did not correlate with disease status in the family. No family had c.634-636delCCA (p.P212del).

In family \#7, a C to A change (c.882C > A, p.H294Q) was identified in $A M B N$, but the substitution (glutamine) is the normal amino acid at that position in mouse and rat ameloblastin. If the rodent homologs can be functional with a glutamine there, we assume that this is also the case for human ameloblastin.

\section{Discussion}

Tooth development initiates as migratory neural crest cells condense beneath the oral epithelium at specific sites along the developing dental arches (69), where cuboidal cells at the base of the oral epithelium multiply and invade the mesenchyme. In response to a series of epithelialmesenchymal interactions, the tooth organ advances through bud, cap, and bell stages $(70,71)$. Genetic disturbances manifested early in tooth formation can arrest tooth development. In humans, tooth agenesis occurs in assorted patterns, and is caused by defects in regulatory genes, usually transcription factors (72). Mutations in $M S X 1$ (73) and $P A X 9$ (74) result in characteristic patterns of oligodontia. When the affected regulatory gene is also involved in developmental processes besides tooth formation, the resulting familial tooth agenesis is a feature of a larger syndrome, such as in ectodermal dysplasia $(75,76)$ or Rieger syndrome (77). It is only when genetic defects are manifested during the later (matrix deposition and calcification) stages of tooth development that isolated malformations occur in the dental hard tissues. Thus, in terms of the etiologies of AI, the principal focus has been on the genes encoding enamel matrix proteins.

The recent discovery that a $D L X 3$ mutation causes AIHHT suggests that the above logic is flawed, but our experience suggests otherwise. Clinical phenotypes and their detection are variables in making a diagnosis. Variable expressivity and penetrance may make the dental phenotype the only one that is clinically evident in some families, but the non-dental symptoms may be subtle and remain undetected. Dental scientists tend to focus on the teeth, while medical scientists tend to ignore them. It is also possible that molecular redundancy may allow relatively normal development to occur in the many systems associated with $D L X 3$ expression.

In our analyses of 24 families with inherited defects in their enamel layer, we learned a number of important lessons. We found that:

- the accepted clinical classification system for AI (2) could not be readily applied to subtype the range of clinical phenotypes we observed in our kindreds;

- the current list of AI candidate genes was insufficient to identify the causative gene defect in most families; and

- we were able to identify and recruit 24 families with inherited enamel defects, but only 10 families with inherited defects of dentin.

This experience gives us the impression that AI might be more prevalent than dentinogenesis imperfecta/dentin dysplasia.

It has been known for some time that defects in the known and suspected candidate genes cannot explain all AI cases (41). In this study, we show that the current list of AI candidate genes is involved in less than half of all cases. This suggests that we know less than we originally thought about the genes/proteins that are specifically critical for dental enamel formation. What might the other relevant candidate genes be? We speculate that additional constituents in the enamel extracellular matrix remain unidentified. We also speculate that some genes/ proteins, which are specifically involved in ameloblast cytodifferentiation and function, await discovery. 
We suspect that the recruitment of large AI kindreds and their characterization by genome-wide searches, as well as better characterization of the constituents in the enamel matrix of developing teeth, will slowly add to the list of AI candidate genes. How will we know when we have identified all of the relevant genes and proteins that collectively cause AI? The best indication will be when genetic analyses of AI kindreds are consistently able to demonstrate that a known AI candidate gene is defective in each affected kindred. Every newly discovered candidate gene will bring us closer to this goal. Once all of the candidate genes associated with AI have been identified, we will better appreciate how the proteins expressed by these genes work together to achieve the biomineralization of dental enamel.

Acknowledgements - We thank Dr Laurence Faivre, MD, PhD, of the Center de Gènètique, Hôpital d'Enfants, France, for providing an AI family. We also thank each family for their participation, and the Pediatric Dental Clinic at the University of Michigan for their cooperation. This investigation was supported by the Foundation of the American Academy of Pediatric Dentistry, and by USPHS Research Grants DE12769, DE15846, and DE11301 from the National Institute of Dental and Craniofacial Research, National Institutes of Health, Bethesda, MD 29892, USA. All authors declare that there are no conflicting interests.

\section{References}

1. Witkop CJ Jr, Sauk JJ Jr. Heritable defects of enamel. In: Stewart RE, Prescott GH, eds. Oral facial genetics. St Louis: C.V. Mosby, 1976; 151-226.

2. WiткоP CJ Jr. Amelogenesis imperfecta, dentinogenesis imperfecta and dentin dysplasia revisited: problems in classification. J Oral Pathol 1989; 17: 547-553.

3. Bäckman B, Holmgren G. Amelogenesis imperfecta: a genetic study. Hum Hered 1988; 38: 189-206.

4. Salido EC, Yen PH, Koprivnikar K, Yu L-C, Shapiro LJ. The human enamel protein gene amelogenin is expressed from both the X and Y chromosomes. Am J Hum Gen 1992; 50: 303316.

5. Berkman MD, Singer A. Demonstration of the Lyon hypothesis in X-linked dominant hypoplastic amelogenesis imperfecta. Birth Defects Orig Artic Ser 1971; 7: 204-209.

6. Simmer JP, SNEAd ML. Molecular biology of the amelogenin gene. In: Robinson C, Kirkham J, Shore R, eds. Dental enamel: formation to destruction. Boca Raton: CRC Press, 1995; 59-84.

7. Akane A, Seki S, Shiono H, Nakamura H, Hasegawa M, Kagawa M, Matsubara K, NAKahori Y, NAgAFUChI S, NAKAGOME Y. Sex determination of forensic samples by dual PCR amplification of an X-Y homologous gene. Forensic Sci Int 1992; 52: 143-148.

8. Steinlechner M, Berger B, Niederstatter H, Parson W. Rare failures in the amelogenin sex test. Int J Legal Med 2002; 116: $117-120$.

9. Chang YM, Burgoyne LA, Both K. Higher failures of amelogenin sex test in an Indian population group. J Forensic Sci 2003; 48: 1309-1313.

10. Lattanzi W, Di Giacomo MC, Lenato GM, Chimienti G, Voglino G, Resta N, Pepe G, Guanti G. A large interstitial deletion encompassing the amelogenin gene on the short arm of the Y chromosome. Hum Genet 2005; 116: 395-401.

11. Hart PS, Hart TC, Simmer JP, Wright JT. A nomenclature for X-linked amelogenesis imperfecta. Arch Oral Biol 2002; 47: 255-260.
12. Lagerström M, Dahl N, Nakahori Y, Nakagome YB, Bäckman B, Landegren U, Pettersson U. A deletion in the amelogenin gene (AMG) causes X-linked amelogenesis imperfecta (AIH1). Genomics 1991; 10: 971-975.

13. Kim J-W, Simmer JP, Hu YY, Lin BP-L, Boyd C, Wright JT, Yamada CJM, Rayes SK, Feigal RJ, Hu JC-C. Amelogenin p.M1T and p.W4S mutations underlying hypoplastic X-linked amelogenesis imperfecta. J Dent Res 2004; 83: 378-383.

14. Sekiguchi H, Kiyoshi M, YakushiJi M. DNA diagnosis of X-linked amelogenesis imperfecta using PCR detection method of the human amelogenin gene. Dent Japan 2001; 37: 109-112.

15. Sekiguchi H, Alaluusua S, Minaguchi K, Yakushiji M. A new mutation in the amelogenin gene causes X-linked amelogenesis imperfecta. J Dent Res 2001; 80: 617.

16. Lagerström-Fermer M, Nilsson MB, Bäckman B, Salido E, Shapiro L, Pettersson U, Landegren U. Amelogenin signal peptide mutation: correlation between mutations in the amelogenin gene (AMGX) and manifestations of X-linked amelogenesis imperfecta. Genomics 1995; 26: 159-162.

17. LENCH NJ, WinTER GB. Characterisation of molecular defects in X-linked amelogenesis imperfecta (AIH1). Hum Mutat 1995; 5: $251-259$.

18. Aldred MJ, Crawford PJ, Roberts E, Thomas NS. Identification of a nonsense mutation in the amelogenin gene (AMELX) in a family with X-linked amelogenesis imperfecta (AIH1). Hum Genet 1992; 90: 413-416.

19. LeNCH NJ, BRook AH, Winter GB. SSCP detection of a nonsense mutation in exon 5 of the amelogenin gene (AMGX) causing X-linked amelogenesis imperfecta (AIH1). Hum Mol Genet 1994; 3: 827-828.

20. Collier PM, Sauk JJ, Rosenbloom SJ, Yuan ZA, Gibson CW. An amelogenin gene defect associated with human X-linked amelogenesis imperfecta. Arch Oral Biol 1997; 42: 235-242.

21. Hart S, Hart T, Gibson C, Wright JT. Mutational analysis of X-linked amelogenesis imperfecta in multiple families. Arch Oral Biol 2000; 45: 79-86.

22. Ravassipour DB, Hart PS, Hart TC, Ritter AV, Yamauchi M, Gibson C, Wright JT. Unique enamel phenotype associated with amelogenin gene (AMELX) codon 41 point mutation. $J$ Dent Res 2000; 79: 1476-1481.

23. Hart PS, Aldred MJ, Crawford PJ, Wright NJ, Hart TC, WRIGHT JT. Amelogenesis imperfecta phenotype-genotype correlations with two amelogenin gene mutations. Arch Oral Biol 2002; 47: 261-265.

24. Greene SR, Yuan ZA, Wright JT, Amjad H, Abrams WR, Buchanan JA, Trachtenberg DI, Gibson CW. A new frameshift mutation encoding a truncated amelogenin leads to X-linked amelogenesis imperfecta. Arch Oral Biol 2002; 47: 211-217.

25. Kindelan SA, Brook AH, Gangemi L, Lench N, Wong FS, Fearne J, Jackson Z, Foster G, Stringer BM. Detection of a novel mutation in X-linked amelogenesis imperfecta. $J$ Dent Res 2000; 79: 1978-1982.

26. Wright JT, Hart PS, Aldred MJ, Seow K, Crawford PJ, Hong SP, Gibson CW, HaRT TC. Relationship of phenotype and genotype in $\mathrm{X}$-linked amelogenesis imperfecta. Connect Tissue Res 2003; 44: 72-78.

27. Krebsbach PH, Lee SK, Matsuki Y, Kozak CA, Yamada K, YAMADA Y. Full-length sequence, localization, and chromosomal mapping of ameloblastin: a novel tooth-specific gene. J Biol Chem 1996; 271: 4431-4435.

28. Hu CC, Hart TC, Dupont BR, Chen JJ, Sun X, Qian Q, Zhang CH, Jiang H, Mattern VL, Wright JT, Simmer JP. Cloning human enamelin cDNA, chromosomal localization, and analysis of expression during tooth development. J Dent Res 2000; 79: 912-919.

29. Deutsch D, Dafni L, Palmon A, Hekmati M, Young MF, FISHER LW. Tuftelin: enamel mineralization and amelogenesis imperfecta. Ciba Found Symp 1997; 205: 135-147.

30. Forsman K, Lind L, Bäckman B, Westermark E, Holmgren G. Localization of a gene for autosomal dominant amelogenesis imperfecta (ADAI) to chromosome 4q. Hum Mol Genet 1994; 3: $1621-1625$. 
31. Kärrman CB, Bä́ckman B, Dixon M, Holmgren G, ForsMAN K. Mapping of the locus for autosomal dominant amelogenesis imperfecta (AIH2) to a 4-Mb YAC contig on chromosome 4q11-q21. Genomics 1997; 39: 164-170.

32. MacDougall M, Dupont BR, Simmons D, Reus B, Krebsbach P, Karrman C, Holmgren G, Leach RJ, Forsman K. Ameloblastin gene (AMBN) maps within the critical region for autosomal dominant amelogenesis imperfecta at chromosome 4q21. Genomics 1997; 41: 115-118.

33. Kim J-W, Seymen F, Lin BP-L, Kiziltan B, Gencay K, SimMER JP, HU JC-C. ENAM mutations in autosomal dominant amelogenesis imperfecta. $J$ Dent Res $2005 ; 84: 278-282$.

34. Hart tC, Hart PS, Gorry MC, Michalec MD, Ryu OH, Uygur C, Ozdemir D, Firatli S, Aren G, Firatli E. Novel ENAM mutation responsible for autosomal recessive amelogenesis imperfecta and localised enamel defects. J Med Genet 2003; 40: 900-906.

35. Hart PS, Michalec MD, Seow WK, Hart TC, Wright JT. Identification of the enamelin (g.8344delG) mutation in a new kindred and presentation of a standardized ENAM nomenclature. Arch Oral Biol 2003; 48: 589-596.

36. Rajpar MH, Harley K, Laing C, Davies RM, Dixon MJ. Mutation of the gene encoding the enamel-specific protein, enamelin, causes autosomal-dominant amelogenesis imperfecta. Hum Mol Genet 2001; 10: 1673-1677.

37. Kida M, Ariga T, Shirakawa T, Oguchi H, Sakiyama Y. The first report of a Japanese family with autosomal-dominant amelogenesis imperfecta caused by an enamelin gene mutation. Arch Comp Biol Tooth Enam 2002; 8: 72-75.

38. Kida M, Ariga T, Shirakawa T, Oguchi H, Sakiyama Y. Autosomal-dominant hypoplastic form of amelogenesis imperfecta caused by an enamelin gene mutation at the exonintron boundary. J Dent Res 2002; 81: 738-742.

39. Mårdh CK, Bä́ckman B, Holmgren G, Hu JC, Simmer JP, Forsman-SEMB K. A nonsense mutation in the enamelin gene causes local hypoplastic autosomal dominant amelogenesis imperfecta (AIH2). Hum Mol Genet 2002; 11: 1069-1074.

40. Kärrman CB, Bäckman B, Holmgren G, Forsman K. Genetic heterogeneity of autosomal dominant amelogenesis imperfecta demonstrated by its exclusion from the $\mathrm{AIH} 2$ region on human chromosome 4q. Arch Oral Biol 1996; 41: 893-900.

41. Hart PS, Wright JT, Savage M, Kang G, Bensen JT, Gorry MC, HART TC. Exclusion of candidate genes in two families with autosomal dominant hypocalcified amelogenesis imperfecta. Eur J Oral Sci 2003; 111: 326-331.

42. Hu JC-C, Zhang CH, Ying Y, Simmer JP. Cloning and characterization of the mouse and human enamelin genes. $J$ Dent Res 2001; 80: 898-902.

43. Hu JC-C, Yamakoshi Y. Enamelin and autosomal-dominant amelogenesis imperfecta. Crit Rev Oral Biol Med 2003; 14: 387 398.

44. Cerny R, Slaby I, Hammarstrom L, Wurtz T. A novel gene expressed in rat ameloblasts codes for proteins with cell binding domains. J Bone Miner Res 1996; 11: 883-891.

45. Hu C-C, Fukae M, Uchida T, Qian Q, Zhang CH, Ryu $\mathrm{OH}$, Tanabe T, Yamakoshi Y, Murakami C, Dohi N, Shimizu M, Simmer JP. Sheathlin: cloning, cDNA/polypeptide sequences, and immunolocalization of porcine enamel proteins concentrated in the sheath space. J Dent Res 1997; 76: $648-657$.

46. Uchida T, Fukae M, Tanabe T, Yamakoshi Y, Satoda $T$, Murakami C, Takahashi O, Shimizu M. Immunochemical and immunocytochemical study of a $15 \mathrm{kDa}$ non-amelogenin and related proteins in the porcine immature enamel: proposal of a new group of enamel proteins sheath proteins. Biomed Res 1995; 16: 131-140.

47. Fukumoto S, Kiba T, Hall B, Iehara N, Nakamura $T$, Longenecker G, Krebsbach PH, Nanci A, Kulkarni AB, YAMADA Y. Ameloblastin is a cell adhesion molecule required for maintaining the differentiation state of ameloblasts. $J$ Cell Biol 2004; 167: 973-983.

48. Lichtenstein J, Warson R, Jorgenson R, Dorst JP, McKusick VA. The tricho-dento-osseous (TDO) syndrome. Am J Hum Genet 1972; 24: 569-582.
49. Wright JT, Kula K, Hall K, Simmons JH, Hart TC. Analysis of the tricho-dento-osseous syndrome genotype and phenotype. Am J Med Genet 1997; 72: 197-204.

50. Hart TC, Bowden DW, Bolyard J, Kula K, Hall K, Wright JT. Genetic linkage of the tricho-dento-osseous syndrome to chromosome 17q21. Hum Mol Genet 1997; 6: 22792284.

51. Price JA, Bowden DW, Wright JT, Pettenati MJ, Hart TC. Identification of a mutation in DLX3 associated with trichodento-osseous (TDO) syndrome. Hum Mol Genet 1998; 7: 563569.

52. Price JA, Wright JT, Kula K, Bowden DW, Hart TC. A common DLX3 gene mutation is responsible for tricho-dentoosseous syndrome in Virginia and North Carolina families. $J$ Med Genet 1998; 35: 825-828.

53. Dong J, Amor D, Aldred MJ, Gu T, Escamilla M, MacDOUGALL M. DLX3 mutation associated with autosomal dominant amelogenesis imperfecta with taurodontism. Am J Med Genet 2005; 133: 138-141.

54. Nusier M, Yassin O, Hart TC, Samimi A, Wright JT. Phenotypic diversity and revision of the nomenclature for autosomal recessive amelogenesis imperfecta. Oral Surg Oral Med Oral Pathol Oral Radiol Endod 2004; 97: 220-230.

55. Bartlett JD, Simmer JP, Xue J, Margolis HC, Moreno EC. Molecular cloning and mRNA tissue distribution of a novel matrix metalloproteinase isolated from porcine enamel organ. Gene 1996; 183: 123-128.

56. Simmer JP, Fukae M, Tanabe T, Yamakoshi Y, Uchida T, Xue J, Margolis HC, Shimizu M, Dehart BC, Hu CC, BARTLETt JD. Purification, characterization, and cloning of enamel matrix serine proteinase 1. J Dent Res 1998; 77: 377-386.

57. Hu JC, Ryu OH, Chen JJ, Uchida T, Wakida K, Murakami C, Jiang H, Qian Q, Zhang C, Ottmers V, Bartlett JD, SimMER JP. Localization of EMSP1 expression during tooth formation and cloning of mouse cDNA. J Dent Res 2000; 79: $70-76$.

58. Simmer JP, Sun X, Yamada Y, Zhang CH, Bartlett JD, Hu JC-C. Enamelysin and kallikrein-4 expression in the mouse incisor. In: Kobayashi I, Ozawa H, eds. Biomineralization: formation, diversity, evolution and application. Hadano: Tokai University Press, 2004; 348-352.

59. Bartlett JD. Enamelysin. In: Barrett A, Rawlings N, Woessner J, eds. Handbook of proteolytic enzymes. San Diego: Academic Press, 2004; 561-564.

60. Simmer JP. Prostase. In: Barrett A, Rawlings N, Woessner J, eds. Handbook of proteolytic enzymes. San Diego: Academic Press, 2004; 1612-1614.

61. Llano E, Pendás AM, Knäuper V, Sorsa T, Salo T, Salido E, Murphy G, Bartlett JD, Simmer JPL, López-Otín C. Identification and structural and functional characterization of human enamelysin (MMP-20). Biochemistry 1997; 36: 15101-15108.

62. Caterina JJ, Shi J, Krakora S, Bartlett JD, Engler JA, KozaK CA, Birkedal-Hansen H. Isolation, characterization, and chromosomal location of the mouse enamelysin gene. Genomics 1999; 62: 308-311.

63. Bartlett JD, Beniash E, Lee DH, Smith CE. Decreased mineral content in MMP-20 null mouse enamel is prominent during the maturation stage. J Dent Res 2004; 83: 909-913.

64. Dupont BR, Hu C-C, Reveles X, Simmer JP. Assignment of serine protease 17 (PRSS17) to human chromosome bands 19q13.3-> q13.4 by in situ hybridization. Cytogenet Cell Genet 1999; 86: 212-213.

65. Hu JC, Zhang C, Sun X, Yang Y, Cao X, Ryu O, Simmer JP. Characterization of the mouse and human PRSS17 genes, their relationship to other serine proteases, and the expression of PRSS17 in developing mouse incisors. Gene 2000; 251: 1-8.

66. Hart PS, Hart TC, Michalec MD, Ryu OH, Simmons D, HONG S, WRIGHT JT. Mutation in kallikrein 4 causes autosomal recessive hypomaturation amelogenesis imperfecta. $\mathrm{J}$ Med Genet 2004; 41: 545-549.

67. Kim J-W, Simmer JP, Hart TC, Hart PS, Bartlett JD, Hu JC-C. MMP-20 mutation in autosomal recessive pigmented hypomaturation amelogenesis imperfecta. J Med Genet 2005; 42: 271-275. 
68. Zambrano M, Nikitakis NG, SancheZ-Quevedo MC, Sauk JJ, SEDANo H, Rivera H. Oral and dental manifestations of vitamin D-dependent rickets type I. report of a pediatric case. Oral Surg Oral Med Oral Pathol Oral Radiol Endod 2003; 95: 705-709.

69. SLAvkin HC. Molecular determinants of tooth development: a review. Crit Rev Oral Biol Med 1990; 1: 1-16.

70. SASAKi T. Cell biology of tooth enamel formation. Functional electron microscopic monographs. Monogr Oral Sci 1990; 14: $1-204$.

71. ThesLefF I. Epithelial-mesenchymal signalling regulating tooth morphogenesis. J Cell Sci 2003; 116: 1647-1648.

72. VASTARDIS H. The genetics of human tooth agenesis: new discoveries for understanding dental anomalies. Am $J$ Orthod Dentofacial Orthop 2000; 117: 650-656.

73. Vastardis H, Karimbux N, Suthua SW, Seidman JG, SeidMAN CE. A human MSX1 homeodomain missense mutation causes selective tooth agenesis. Nat Genet 1996; 13: 417-421.

74. Stockton DW, Das P, Goldenberg M, D'Souza RN, Patel PI. Mutation of PAX9 is associated with oligodontia. Nat Genet 2000; 24: 18-19.
75. Kere J, Srivastava AK, Montonen O, Zonana J, Thomas N, Ferguson B, Munoz F, Morgan D, Clarke A, Baybayan P, Chen EY, Ezer S, SaArialho-Kere UDI, Chapelle A, SCHLESSINGER D. X-linked anhidrotic (hypohidrotic) ectodermal dysplasia is caused by mutation in a novel transmembrane protein. Nat Genet 1996; 13: 409-416.

76. Bayes M, Hartung AJ, Ezer S, Pispa J, Thesleff I, SRIVASTAVA AK, Kere J. The anhidrotic ectodermal dysplasia gene (EDA) undergoes alternative splicing and encodes ectodysplasin-A with deletion mutations in collagenous repeats. Hum Mol Genet 1998; 7: 1661-1669.

77. Semina EV, Reiter R, Leysens NJ, Alward WL, Small KW, Datson NA, Siegel-Bartelt J, Bierke-Nelson D, Bitoun P, Zabel BU, Carey JC, Murray JC. Cloning and characterization of a novel bicoid-related homeobox transcription factor gene, RIEG, involved in Rieger syndrome. Nat Genet 1996; 14: 392-399. 